\title{
THE RATE OF RETURN IN AIR TRANSPORT
}

\author{
Paul L. HowelL*
}

\section{Comparison With Other Transport Agencies ${ }^{1}$}

A "fair and reasonable rate of return" in the sense of Smyth v. Ames, Bluefield" Water Works, ${ }^{3}$ and Hope Natural Gas ${ }^{4}$ scarcely exists today for the major forms of transportation: railroads, ${ }^{5}$ motor-vehicle common carriers, ${ }^{6}$ urban transit, water transport, and airlines. Except for oil ${ }^{7}$ and gas $^{8}$ pipelines, the transport agencies present such special situations that the rate-of-return problem in its classical sense is hardly applicable.

For years, the railroads have not earned a rate of return that would attract capital, and currently they have such a passenger deficit ${ }^{9}$ that the question of exceeding, or even of attaining, a fair return on a fair value has not been given serious consideration in proceedings before the Interstate Commerce Commission ${ }^{10}$ or state commissions. ${ }^{11}$

- B.B.A. I93I, M.A. I934, University of Washington; M.A. I942, Harvard University. Partner, Paul Howell Associates, New York, N.Y.; Treasurer, Welfare, Pension \& Equity Plans Services, Inc., New York, N.Y. Consulting Economist to the United States Civil Aeronautics Board, New York Public Service Commission, Massachusetts Department of Public Utilities, Vermont Public Service Commission, United States Antitrust Division of the Department of Justice, United States Securities and Exchange Commission, New York Stock Exchange, Blue Cross Association of America, and other civic, industrial, and trade groups. Securities Analyst, Utility Division of the United States Securities and Exchange Commission, r940-47; Associate Professor of Finance, Graduate School of Business Administration, New York University, x94856; Visiting Professor of Finance, Columbia University, 1950-58; Visiting Professor of Finance, University of California at Los Angeles, 1959. Author, A Fair and Reasonable Rate of Return for Domestic Trunkline Air Carriers (1957), Investment of Pension Funds (1959). Contributor to economic and financial periodicals.

${ }^{1}$ For other aspects of regulation of air transport, see sympasia Air Cargo, ${ }_{5}$ Law \& CoNtemp. Prob.. I (1950), Aviation Transport, II id. at 429 (1946).

${ }^{2}$ r6g U.S. 466 (1898).

3 Bluefield Water Works \& Improvement Co. v. Pub. Serv. Comm'n of West Virginia, 262 U.S. 689 (1923).

¿FPC v. Hope Natural Gas Co., 320 U.S. 59 I (I944).

- Sidney L. Miller \& Virgiz D. Cover, Rates of Return Cliss I Line Haul Railways, ig2i-i948 (I950).

${ }^{\circ}$ Clyde B. Artchison, fair Reward and Just Compensation, Common Carrier Service (1954).

${ }^{7}$ Reduced Pipe Line Rates and Gathering Charges, 243 I.C.C. I15 (I940), 272 I.C.C. 375 (I948).

${ }^{8}$ FPC v. Panhandle Eastern Pipeline Co., 324 U.S. 635 (1945); FPC v. Hope Natural Gas Co., 320 U.S. 49r (I944); FPC v. Colorado Interstate Gas Co., 324 U.S. 58I (I945); Northern Natural Gas Co. v. FPC, 206 F.2d 690 (8th Cir. 1953); Panhandle Eastern' Pipe Line Co., 3 P.U.R.3d 396 (FPC 1954); United Fuel Gas Co., I2 F.P.C. 25I (1953); Michigan-Wisconsin Pipe Line Co., FPC Opinion No. 275 (July 28, I954); symposium The Regulation of Natural Gas, I9 LAw \& Contemp. Prob. 323 (x954); Howell \& Hart, The Promoting and Financing of Transcontinental Gas Pipe Line Corporation, $7 \mathrm{~J}$. Finance 3 II (195I).

- National Ass'n of Railroad and Utiljties Comm'rs, Special Committee to Study the Railroad Passenger Defictr Problem, Reports (1953-58). See also Railroad Passenger Train Deficit, No. 3I954,Examiner's Proposed Report, ICC, Sept. I8, 1958.

${ }^{10}$ In I95x, this Commission commented as follows: "Judged by any standard the rates of return carned or prospectively to be earned by the railroads . . . are substandard." Increased Freight Rates, I95I,- 
Indeed, this has been true since the $O^{\prime} F a l l o n$ case ${ }^{12}$ sounded the death knell of the recapture provision of the Transportation Act of $1920 .{ }^{13}$ Earnings of motor common carriers also are severely limited by competition. Urban transit has been almost completely taken over by municipalities because private agencies were not able to meet rising wages, taxes, and other expenses. Inland and ocean water transport is supported by considerable subsidy in many forms.

Until 195x, when the "Big Four" of the domestic trunk lines (American, United, Eastern, and TWA) were placed on cost rates for carrying mail, ${ }^{14}$ the growing industry of air transport was also heavily subsidized; and local service air carriers are still on subsidy. ${ }^{15}$ Today, eight years later, the Civil Aeronautics Board is laboring to adapt traditional concepts to meet modern operating conditions in commercial aviation. ${ }^{16}$ This paper will appraise the suitability of these concepts for this dynamic young transport industry so vital to our economy and national defense.

II

Economic Requirements-A Rate of Return That Will Attract Capital

A "fair and reasonable rate of return" is that return which is necessary to avoid constitutional prohibitions against the confiscation of property. This, however, is a somewhat negative legalistic approach; its further development will be left to the courts.

The second, or economic, approach considers what the public must pay to obtain employment of the factors of production necessary to furnish the desired service. ${ }^{17}$ The abstract concept, "fair and reasonable rates," becomes meaningful, then, in light of the end to be achieved-fares that will provide sufficient revenues to compensate for all costs of rendering that service. Among such costs must be included a return sufficient to attract capital.

The supply price of capital should be the paramount consideration of a utility commission in setting over-all rate levels. If this economic standard is not met, even though the constitutional standards are technically satisfied, the public, whom regulation is designed to protect, will not be rendered the desired quality of service. A cap-

284 I.C.C. $589,6 \pm 2$ (1952), 297 I.C.C. 17,49 (1955). See also Increased Freight Rates, 1956, 300 I.C.C. 633 , esp. 687 (1957); Increased Express Rates and Charges, 1957, Ex parte No. 210, ICC, Oct. 13, 1958; Increased Freight Rates, 1958, 304 I.C.C. 289 (1958); Railway Mail Pay-Application of Eastern Railroads, I956, 304 I.C.C. I35 (I958); agreements of Rail Carriers, Post Office, and the ICC, dated Dec. 30, 1957. For the past decade, Class I railroads have averaged earnings of $3.68 \%$ on "net investment" (original cost less recorded depreciation and amortization); in 1958, the return was $2.76 \%$. james C. Nelson, Railroad Transportation and Public Policx ch. 7 (i959).

${ }^{1 x}$ N.Y. Pub. Serv. Comm'n, Report of Investigation of the Financial Condition of thie Raizroads Operating in the State of New York (1959).

${ }^{12}$ St. Louis \& O'Fallon Ry. Co. v. United States, 279 U.S. 46 I (1929).

134 Stat. 157.

14 American Airlines, et al., Mail Rates, 14 C.A.B. $55^{8}$ (1951).

${ }^{15}$ Rate of Return of Local Service Carriers, No. 8404, CAB (1956).

${ }^{18}$ General Passenger Fare Investigation, No. 8008, CAB, May 10, 1956.

17 Towne, The Problem of a Fair Rate of Return, rg ICC Prac. J. 357 (1952); FPC, The Prodlem of the "Rate of ReturN" in Public Utality Regulation ch. 2 (1938). 
ital-attracting rate of return is particularly needed to enable a new industry like air transport to serve the growing needs of modern business.

It should be noted that the investors' return for the use of their capital is referred to here as a "cost." No allowance is made for profit; to the extent there is risk in the business, this risk enters into the supply price of the capital and becomes a cost that consumers must pay. ${ }^{18}$ The supply-price approach emphasizes what must be earned to attract capital in the future. Its view is forward-looking.

The key question for the economic or financial approach is this: What revenues do the carriers need, in the light of operating expenses and income taxes, to provide a return which will enable the carriers to (a) maintain the financial integrity of their working capital position; (b) compensate investors for the risk to their capital; (c) pay interest and dividends; and (d) attract additional capital for expansion on favorable terms? The answer to this question, when related to the appropriate capital base, constitutes the framework for a fair and reasonable rate of return.

Pause for a moment to consider an equity investor's requirements. A casual inspection of the financial page demonstrates that common stockholders are interested in the return on capital outlay, in the form of earnings, dividends, and/or capital appreciation. What return capital requires is determined in the competitive market place by weighing the many investment alternatives and including risk of loss and speculative gain possibilities. This evaluation underlies the going market rate that must be paid for capital by those who wish to use it in providing their service.

It is well known that most investors do not know either what is the "value" of the property being committed to utility service or what is the rate of return thereon. Both are computed according to technical rate-proceeding rules and vary considerably from jurisdiction to jurisdiction, or even from utility to utility in the same jurisdiction, or even for the same utility over a period of time.

As stated in the immortal words of Mr. Justice Brandeis: ${ }^{19}$

The thing devoted by the investor to the public use is not specific property, tangible and intangible, but capital embarked in the enterprise. Upon the capital so invested the Federal Constitution guarantees to the utility the opportunity to earn a fair return.

Consequently, to take a market-established cost of capital and apply it to an artificially-define property base results in a nonhomogeneous mixture of oranges and apples. Instead of complicated determinations of the "value of property" devoted to public service, the rate base should be the sums devoted to the enterprise under "honest, economical, and efficient" financing-that is, the right-hand side of the balance sheet. Unfortunately, judicial treatment of this problem has often been an archaic hangover from the law of eminent domain and has had little direct relationship to the economic task confronting administrative agencies in setting rates that will attract the capital needed to supply the desired service.

\footnotetext{
${ }^{28}$ Frank Knight, Risk, Uncertainty, and Profit (I921).

${ }^{19}$ State ex rel. Southwestern Bell Telephone Co. v. Pub. Serv. Comm'n of Missouri, 262 U.S. 276, 290 (1923) (concurring opinion of Justice Brandeis).
} 
III

\section{Early Treatment of Rate of Return by the CAB}

A. Mandate of the Federal Aviation Act

Congress, in section I02 of the Federal Aviation Act, ${ }^{20}$ has directed the CAB, inter alia, to (a) encourage and develop an air transportation system adapted to the needs of commerce, the Postal Service, and the national defense; (b) regulate air transport in such manner as to foster sound economic conditions; and (c) promote adequate, economical, and efficient service by air carriers at reasonable charges.

As a guide, section $1002(e)^{21}$ sets forth a rule of rate-making whereunder the Board, with respect to the determination of rates for air carriage, should consider, among other factors:

(I) The effect of such rates upon the movement of traffic;

(2) The need in public interest of adequate and efficient transportation of persons and property by air carriers at the lowest cost consistent with the furnishing of such service;

(3) Such standards respecting the character and quality of service to be rendered by air carriers as may be prescribed by or pursuant to law;

(4) The inherent advantages of transportation by aircraft; and

(5) The need of each air carrier for revenue sufficient to enable such air carrier, under honest, economical, and efficient management, to provide adequate and efficient air carrier service.

\section{B. Mail Subsidy and Its Relation to the Rate of Return}

The attention of the $\mathrm{CAB}$ has been directed primarily to mail rates and the subsidy provisions relating to the "need" of the carriers. Section $406(\mathrm{~b})$ provides that in fixing and determining fair and reasonable rates of compensation, the Board shall take into consideration: ${ }^{22}$

... the need of such air carrier for compensation for the transportation of mail sufficient to insure the performance of such service, and, together with all other revenue of the air carrier, to enable such air carrier, under honest, economical, and efficient management, to maintain and continue the development of air transportation to the extent and of the character and quality required for the commerce of the United States, the Postal Service, and the national defense.

Early in the administration of the Act, the Board made some policy decisions. In view of the absence of reliable data, the newness of the industry, and the Board's responsibilities for subsidies, the $C A B$ determined that a seven per cent return was adequate in making retroactive adjustments in mail rates. In setting mail rates for past periods, it was felt that the risk factor had been eliminated and so there was no need for it to be compensated.

${ }^{30} 72$ Stat. 740,49 U.S.C.A. $\$ 1302$ (Supp. I958), formerly Civil Aeronautics Act $\$ 2,52$ Stat. 980 (1938), 49 U.S.C. \$ 402 (1952).

${ }_{22} 72$ Stat. 789,49 U.S.C.A. $\$ 1482$ (e) (Supp. 1958).

${ }^{23} 72$ Stat. 763,49 U.S.C.A. $\$ 1376$ (b) (Supp. 1958). 
Mail rates for the future were to be set with the objective of enabling the carrier, under honest, economic, and efficient management, to earn an over-all rate of return of eight per cent on invested capital. These figures were not developed from elaborate capital market studies, but were adopted by the use of the Board's expert administrative discretion in setting policy for subsidy payments. ${ }^{23}$

In considering mail subsidy payments for international air operations, the Board and its staff for the first time made an extensive analysis of the cost of attracting capital. Examiner Radcliffe, after studying extensive exhibits and testimony with respect to investor receptiveness for airline securities, found 9.3 per cent to be a fair and reasonable over-all rate of return. ${ }^{24}$ The market evaluation of airline securities, as indicated by earnings-price ratios prior to $195^{2}$, showed great variation among carriers and timewise. The postwar airline depression of I946-47 and later the Korean airlift boom gave great instability to earnings-price ratios. The Board, with data for an additional year and a half to guide it, concluded that a nine per cent return would attract capital on advantageous terms. ${ }^{25}$ The opinion also contained language indicating that the Board felt the overseas operations to be somewhat more hazardous financially and entitled to a flat one per cent increase in return over that allowed to domestic operations.

In the postwar period, the carriers (with the exception of Eastern), as a result of reduced fares and mail rates, increased costs, increased capacity, and lower load factors, incurred substantial losses. Not until I95I, after more than twenty years of operation, were the four large carriers sufficiently on their financial feet to get off mail subsidies; and Northeast, the last of the trunklines, went off subsidy in $1959 .^{26}$

\section{The 1952 General Passenger Fare Investigation}

Early in 1952 , the carriers, concerned with falling off of the Korean War activities, rising costs, and additional equipment that resulted in lower load factors, were alarmed by the decline of profits. The leading carriers filed (a) to have all tickets increased by one dollar, and (b) to eliminate the five per cent round-trip discount. The Board, though not unanimous, permitted the one-dollar increase to go into effect, thus giving the industry for the first time a "tapering" fare recognition of the greater

as Paul W. Cherington, Atrline Price Policy: A Study of Airline Passenger Fares ch. 3 (1958). See Trans-Atlantic Final Mail Rate Case, Ig C.A.B. 464 (I954).

at See Examiner's Initial Decision (1953), reprinted in Trans-Atlantic Final Mail Rate Case, I9 C.A.B. 464,528 (1954).

36 Ibid.

${ }^{20}$ For the "Big Four" see note 14 supra. In removing Northeast from subsidy mail rates, the CAB said: "We still believe that Northeast should be self-sufficient, although as of this date it has not attained self-sufficiency." In the Matter of Northeast Airlines, Inc., No. 8497, Order and Opinion No. E-13465, CAB, Feb. 3, 1959 , p. 4. In its report to stockholders covering the year r958, Northeast reported a net loss of $\$ 4,640,000$ after mail subsidy payments of $\$ 2,386,000$. This carrier has encountered difficulty in penctrating the highly competitive New York-Florida market, as was anticipated by CAB Members Gurney and Denny. See New York-Florida Route Case, No. 305I, Order No. E-I0645, CAB, Sept. 28, 1956. See also the examiner's initial decision in that proceeding, which favored making Deita the additional New York-Florida carrier. Northeast reports an operating deficit for the first 9 months of 1959 of $\$ 2,600,000$. 
terminal cost of short-haul business. ${ }^{27}$ The five per cent discount was denicd, but a general investigation of passenger fares was initiated. ${ }^{28}$

With the resurgence of carrier earnings, the carriers, asserting the great expense and the vagueness of the issues involved, pressed for dismissal of the 1952 General Passenger Fare Investigation. Some carriers also urged the substitution of an operating-ratio approach for the rate-of-return concept as a measure for the reasonableness of earnings. ${ }^{2 \theta}$

After much discussion and with sharp differences of opinion, the majority of the Board dismissed the proceeding with this statement of policy: ${ }^{30}$

It is our intent to examine any future fare or mail rate proposals, not only in the light of conditions prevailing at the time they are advanced but with full consideration of the abnormal earnings of prior years and the excess earnings which may be expected in the future, as indicated by such experience. In short, should earnings fall markedly in the future the carriers will be expected to absorb such losses without resort to fare or mail rate adjustments unless it can be demonstrated that such earnings are below the level necessary to provide a fair return over a reasonable extended period which includes the good years as well as the bad.

Members Lee and Adams dissented vigorously to the dismissal of this proceeding. One of their chief objections was to the ad hoc approach of the Board and its being buffeted about by immediate crises without a long-range program or policy. Adams, in particular, emphasized that the Board had never made a study of the facts in a formal proceeding and thus had no reliable information from which to establish a policy and reach a conclusion as to the fairness and reasonableness of rates.

\section{IV}

\section{I956 General Passenger fare Investigation}

\section{A. Causes and Objectives}

This lack of information set the stage for the next act. Late in 1955, the Comptroller General submitted reports to Congress that were sharply critical of methods used in determining airline subsidies and rates for the haulage of mail.1. Early in 1956, the House Antitrust Subcommittee, headed by Emanuel Celler, held extensive hearings on competition in the airlines and the reasonableness of rates. ${ }^{32}$ About this time, too, under the leadership of the new Chairman, James R. Durfee, the Board voted to make an extensive investigation of airline fares in three major proceedings:

\footnotetext{
${ }^{27}$ See Cherington, op. cit. supra note 23, at 100-02.

${ }^{28}$ General Passenger Fare Investigation, No. 5509, Order No. E-6305, CAB, April 2, 1952.

${ }^{29}$ See Cherington, op. cit. supra note 23 , at I04.

so General Passenger Fare Investigation, No. 5509, Order No. E-7376, CAB, May 14, 1953.

31 Joseph Campeeli, Audit Report to Congress re the Civil Aeronautics Board (x955) (filed April 9, I956).

${ }^{82}$ Hearings Before the Antitrust Subcommittee of the House Committee of the Judiciary on Monopoly Problems in Regulated Industries, $84^{\text {th }}$ Cong., $2 d$ Sess. pt. I, vols. I-4 (1956).
} 
I. the 1956 General Passenger Fare Investigation; ${ }^{33}$

2. The Rate of Return of Local Service Carriers; ${ }^{34}$ and

3. the Capital Gains Proceeding. ${ }^{35}$

The 1956 General Passenger Fare Investigation was instituted following a period of six years during which the trunkline industry enjoyed the highest level of profits in its history. As pointed out in the Board's opinion and order fixing the scope of the issues: $:^{36}$

What led to the institution of this investigation was [the Board's] concern, based on the level of earnings reported by most of the respondents, over the possibility that the public was being subjected to excessive charges, over-all, for passenger transportation.

In accordance with that order, the two main purposes of the 1956 General Passenger Fare Investigation are: ${ }^{37}$

(I) to develop appropriate and well-defined standards respecting the earnings required by the domestic trunkline carriers for proper development consistent with the public interest; and

(2) based on such standards, to require or permit such overall decreases or increases in domestic fares as the facts may warrant.

\section{B. The Suspended Passenger Fare Increase Case}

The short-term approach to the airline problems which has been so characteristic has been noteworthy in this proceeding. When the General Passenger Fare Investigation started out early in $195^{6}$, the premise seemed to be that rates might be too high and perhaps should be reduced; the carriers were dragging their feet with delaying tactics. Within eight months, the carriers had completely changed their position; they began to allege that earnings were entirely inadequate and to urge that matters be expedited. In January I957, most of the trunkline carriers filed tariffs for increased rates, which were immediately suspended and consolidated for hearing. ${ }^{38}$ Informally this was referred to as the " $6 \%$ fare case," and its docket was given precedence over the 1956 General Passenger Fare Investigation, which was recessed.

The carriers contended, during extensive hearings, that earnings had fallen precipitously and that they were in need of emergency relief which could not await determination of the broader issues. The staff of the Bureau of Air Operations (BAO) argued that the carriers faced a temporary situation and that the issues should not be decided by a "keyhole" approach. On September 25, I957, by a vote of three to two, the Board, regarding the then-current low. earnings as a temporary phe-

\footnotetext{
${ }^{83}$ General Passenger Fare Investigation, No. 8008, Order No. E-10279, CAB, May 10, I956.

${ }^{84}$ Rate of Return of Local Service Carriers, No. 8404, Order No. E-10843, CAB, Dec. ro, I956.

${ }^{35}$ Capital Gains Proceeding, No. 7902, Order No. E-1 2855, CAB, Aug. I, 1958.

${ }^{38}$ General Passenger Fare Investigation, No. 8008, Order No. E-r0488, CAB, July 27, r956, p. 2.

${ }^{37}$ CAB Ann. Rep. 9 (I956).

${ }^{38}$ Suspended Passenger Fare Increase, No. 8613, Order E-I18I2, CAB, Sept. 25, 1957.
} 
nomenon, rejected applications for increased rates. ${ }^{39}$ On January 8, 1958, the Board rejected petitions for reconsideration, because they "failed to establish that relief requested is warranted."40

TWA, followed by Capital, immediately filed new and higher tariffs providing for a fifteen per cent increase in rates plus a dollar a ticket. On January 24, 1958, just two weeks after denial of increases in the Suspended Passenger Fare Increase case, the Board announced, in a press release, that it was denying TWA's filing, but that it would be receptive to filings which increased fares by four per cent plus a dollar a ticket. The suggested action was immediately taken by the trunklines.

The Board, in its subsequently-published opinion, stated that it had acted on the basis of recently-prepared staff memoranda ${ }^{41}$ and earnings reports specially requested from the carriers. One member dissented on the basis that it was "too little and too late." Board member Minetti filed a delayed dissent sharply critical of the pressure tactics of the carriers and the lack of definitive data. ${ }^{42}$

Seven months later, the carriers, with approval of the Board, eliminated stop-over privileges, withdrew round trip discounts, and reduced family-fare discounts-action which increased rates about four per cent. ${ }^{43}$

\section{Supply Price of Capital for Domestic Trunk Carriers}

To pay the economic cost of attracting capital, a rate of return must be provided which will (a) maintain the utility's "financial integrity"; (b) cover interest, allow reasonable dividends, and permit something to be added to surplus in normal times as a margin of safety; and (c) provide the ability to sell stocks on advantageous terms in the competitive market. A return which fulfills these goals should not only properly balance the interests of consumers and investors, but also meet the requirements of sections two and I002 of the Civil Aeronautics Act by being "promotional" in character. ${ }^{44}$

For proper analysis, it is necessary to consider in detail what is the supply price of capital for domestic air lines. This, in turn, involves a determination of (a) the cost of debt capital; (b) the cost of equity capital; and (c) an appropriate capital structure.

\section{x. Cost of debt capital for airlines}

As the 1956 General Passenger Fare Investigation went on, interest rates increased. Since utility rates are made for the future, regulating authorities must make allowance for future contingencies. In the case of debt, the problems revolve around the amount of debt-financing to be done and at what rate.

${ }^{39}$ Id., Order No. E-11812, Sept. 25, 1957.

${ }^{10}$ Id., Order No. E-1 2092, Jan. 8, 1958.

$\$ 1$ See General Passenger Fare Investigation, No. 8008, Bureau Counsel Exhibit No. 120, $A$ Fair and Reasonable Rate of Return for Domestic Trunkline Air Carriers, CAB, Oct. 15, 1957 [prepared by Paul Howell Associates and hereinafter cited as Howzur Exmirr].

42 TWA, et al., Interim Fare Increase, No. 9288, Order No. E-12203, CAB, Feb. 25, 1958. See Board member Minetti's dissent, dated April r6, r958.

${ }^{\wedge}$ Withdrawal of Round-Trip Discounts and Related Matters, No. 993r, Order No. E-x3066, CAB, Oct. I4, 1958; CAB press releases 58-64 and 58-63, Oct. 14, 1958 .

is See supra notes 20-2I. 
In general, counsel and witnesses for the airlines contended that current money rates should be the chief factor in determining the proper rate for obtaining this component of capital, even though much debt had already been contracted at substantially lower levels. Future costs, the carriers contended, were particularly important, because the airlines had heavy demands for capital to equip themselves for the jet age. The carriers emphasized the uncertainties with respect to future borrowing rates and their debt-selling ability. On the other hand, several carriers had been unusually far-sighted and had secured substantial forward commitments from insurance companies for long-term funds. ${ }^{45}$ This circumstance enabled them to have a low over-all future debt cost.

Bureau counsel contended that existing debt cost should be the primary guide and that future borrowing rates were conjectural. ${ }^{48}$ An independent financial consultant for the BAO testified to a dual rate for the industry. ${ }^{47}$ For the "Big Four" (American, United, Eastern, and TWA), four per cent was deemed a fair over-all cost of debt capital, after taking into consideration the cost of existing debt loan commitments, projected new borrowing, and the probable interest costs. ${ }^{48}$ Debt costs for the smaller trunkline carriers varied considerably. The Bureau's witness concluded that 4.8 per cent was a reasonable group rate to use for these carriers, which in general did not have so good a credit rating.

\section{Cost of attracting equity capital}

Most rate-of-return cases center on the earnings which are necessary to attract equity capital for the utility on advantageous terms. Among the standards which have been used in this connection are these:

r. maintenance of earnings per share;

2. maintenance of established cash dividends;

3. allowance of sufficient earnings to maintain market price equal to book value;

4. allowance of sufficient earnings to maintain market price at some predetermined level above book value equal to or in excess of the stock's "acquisition cost"; and

5. maintenance of financial integrity.

Earnings should be sufficient so that additional shares can be sold under competitive conditions at a price which would not result in a material dilution of their book value. Stockholders in a business "affected with a public interest" a reasonable return on the sums invested therein. They are not entitled to earnings

\footnotetext{
"E.g., in 1955, American contracted with Metropolitan Life Ins. Co. for $\$ 75,000,000$, to be taken down over the next four years at a $4 \%$ rate, to run until 1996 , a period of forty years.

${ }^{40}$ General Passenger Fare Investigation, No. 8008, Bureau Counsel Brief, CAB, Oct. 29, 1958, pp. I7074 [hereinafter cited as Bureau Brief].

${ }^{17}$ To assist the BAO with the financial aspects of the rate of return, the Board retained Paul Howell Associates, as independent financial and utility consultants.

${ }^{88}$ Sec Howell. Exinbit \$3. ${ }^{4}$ Muna v. Illinois, 94 U.S. II3 (I877).
} 
which would make the stock sell far in excess of the sums invested in the business, for that would exceed the competitive market supply price..$^{50}$

a. Market capitalization rates-earnings/price ratios. The difficulty is that equity capital markets are never static. The orthodox approach to measuring what is necessary to induce investors to convert their free funds into airline equities relates the market price of airline shares to their concurrent earnings-that is, how much investors will pay for a dollar of earnings. The resulting earnings/price ratio is only a first approximation of the investor's asking price. Although these market ratios can be computed exactly, they may not reflect the true cost of attracting capital, except in a stable situation. In buying stock, investors are paying the present worth of all expected future earnings. What earnings expectation the investor has in mind is not known, nor is the rate at which he is capitalizing hopes or discounting risks. Even so, concurrent earnings/price ratios provide the foundation and the "best evidence" of the supply price for equity capital. Such ratios, when computed during a stock market boom, must, however, be used with great caution in attaining sound regulatory objectives. ${ }^{\text {.1 }}$

In long-established, stable enterprises, a quite precise determination of the market supply price can be made. Airlines, however, have only begun, since I95I, to achieve a self-reliant status independent of subsidy. Earnings/price ratios have been not only variable, but also considerably higher than those of the established electric utilities. Airline earnings/price ratios, rather than those of other utilities, should be given primary weight, since only they take into consideration the unique operating aspects of air transport, such as capital structure, operating ratio, earning and dividend record, competitive routes, technical obsolescence, occupational hazards, labor conditions, capital turnover, capital gains, and special legislation.

Matters like length of time to be reviewed, relative weight to be given to more recent market data, and comparisons with other companies are important in the measurement of the particular situation; but usually they do not involve conceptual difficulties.

It is relatively easy to come to a determination of a capital-attracting rate of earnings for a single company. More difficulties are involved when making such a determination for a group of companies, especially when they have such diverse records as the twelve trunk carriers. The Bureau's independent consultant concluded that the "Big Four" had sufficiently similar conditions for attracting capital so that they could be grouped together; and he considered that eleven per cent represented a

${ }^{\circ}$ Cf. Bluefield Water Works \& Improvement Co. v. Pub. Serv. Comm'n of West Virginia, 262 U.S. 689 (r923).

${ }^{51}$ For a detailed discussion of the technical and financial application of earnings/price ratios to the measurement of the supply price of airline capital, see Howerr ExHırt \$ 4. See also Zinbarg, $A$ Study of Industrial Common Stock, The Analyst's Journal, Aug. I959, p. 35, in which, after an claborate statistical analysis, the "widespread practice of relating the current year's prices to the current year's earnings and dividends when utilizing the concepts of price-earnings ratios and yields" is endorsed. 
fair market capitalization rate of expected earnings. ${ }^{52}$ On the basis of earnings/price ratios which were much more dispersed, it was concluded that twelve per cent was a fair discount rate for the remaining eight trunkline carriers.

The statute requires a consideration of the needs of each carrier. In general, the smaller carriers have poorer earnings and dividend records, and consequently greater costs of raising capital. The important thing for some of them was not whether their cost of attracting capital was fifteen per cent, as asserted, but whether they could even earn eight per cent with any degree of regularity in competition with other transport agencies.

The fundamental problem of how to implement a two-level rate of return, so that the weak carriers could earn more than the strong carriers, which have a lower cost of capital built into their rate of return, was left by the $\mathrm{CAB}$ to forthcoming proceedings on fare structure. The analogous weak-and-strong-railroad problem has not been dented by the ICC since the passage of the Transportation Act of I920. As for the airlines, the basic solution seems to lie not in fare structure, but in the modification of competitive conditions, route structures, and mergers. Many felt, for example, that the solution to the problems of Northeast Airlines did not lie in an attempt by a weak carrier to penetrate the highly competitive Miami route on its own, but instead in penetration by a merger with National Airlines..$^{53}$

A technical matter, almost unique to airlines, is the handling of capital gains and losses in determining what earnings figures should be used in computing or calculating earnings/price ratios. Some carriers have been quite remiss in not pointing out in their annual reports the nonoperating character of a substantial portion of the reported "net income" per share. Many investors are not fine-print reading professional analysts, but rely on the earnings as given by the carrier to the financial press. During the 1956 General Passenger Fare Investigation, no adjustment was made by some witnesses to eliminate capital gains from reported earnings. The Bureau counsel's witness testified, however, that a "fair and reasonable rate of return"

"Sowell Exhibit $\$ 4$. As of I8 months later (May 1959), the pertinent financial data for the "Big Four" were as follows:

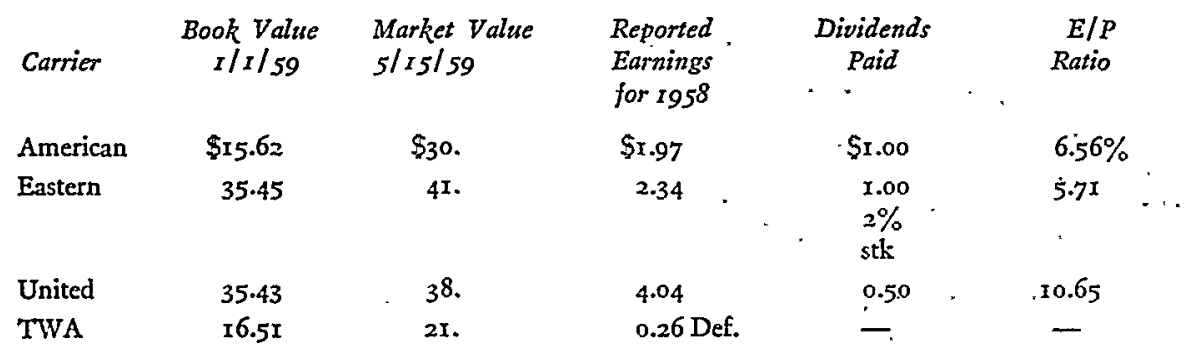

American, Eastern, and TWA were affected by strikes and bad weather in 9958 .

s New York to Florida Route, No. 305x, et al., Order No. E-10645, CAB, Sept. 18, 1956 (see dissenting opinion). 
should be based on net operating profits without regard to the remote contingency of uncertain net capital gains at some time in the future. ${ }^{54}$

b. Adjustment of earnings/price ratios to allow for "costs of acquisition" of additional airline equity. Ordinarily, additional equity financng can only net the company treasurer something less than the market price of the outstanding shares. These lower net proceeds reflect the "cost of acquisition" and are accounted for by company cash financing expenses, underwriting commissions, noncash discounts to allow for market pressure of the additional shares being offered, and possibilities of a break in market prices. ${ }^{55}$ True "cost of acquisition" does not include any allowance for large discounts when share subscriptions are offered to existing stockholders at prices far below the market.

The true capital-attracting rate of return is the earnings/net proceeds ratio. Since frequently such data are not available, the market capitalization rates-the earnings/ price ratios-are used as a starting point, and an adjustment is made for the "costs of acquisition." To finance on "advantageous terms" means that earnings must be sufficiently high so that new shares can be sold without impairing the position of existing security holders-to net the treasurer at least book value under normal conditions.

Witnesses during the 1956 General Passenger Fare Investigation differed widely in their concept of "underpricing" and in methods of adjusting the earnings/price ratios therefor. Their final allowances, however, were quite close together, ranging from a ten per cent to a fifteen per cent increase of the earnings/price ratios. As to the adequacy of this adjustment, it may be noted that Pan American World Airways, vigorous in espousing its own cause, contended for no more than a fifteen per cent underpricing allowance. ${ }^{56}$ In general, an adjustment of fifteen per cent should accomplish the following:

I. enable airline stocks to sell at prices which average fifteen per cent above book value;

2. enable the "net proceeds" of future sales, under ordinary competitive conditions, to exceed book value and thus prevent dilution;

3. provide adequate margin for out-of-pocket costs and the noncash costs of floating equity shares; and

Et With respect to local carriers on subsidy, the Board, with two members dissenting, has taken the position that capital gains must be considered in the over-all picture (as other income) in sctting mail rates on a noncost basis. Capital Gains Proceeding, No. 7902, Order No. E-12855, CAB, Aug. 1, 1958.

${ }^{85}$ Howell, Competition in the Capital Markets, Harv. Bus. Rev., May 1953, p. 83.

88 “. . . . Another factor which has an' important bearing on Pan American's ability to sell stock on fair terms is the relationship between the market value and book value of Pan American's stock. It is a fundamental rule of public utility rate regulation that public utilities must be able to sell additional capital without diluting the value of the shares already outstanding. Since certain expenses are involved in a stock issue, and since any new issue must, for practical reasons, be priced somewhat below the market, it is a good rule of thumb that stock must sell on the market at no less than $115 \%$ of book value for the company to be able to net book value on a new issue." Testimony of R. G. Ferguson, Treasurer, Pan American World Airways, Capital Gains Proceeding, No. 7902, PAA Exhibit, CAB, Oct. 1956, p. I6. 
4. more than offset any dilution of earnings, since the adjusted rate of return is applied to all the equity and not just the new shares.

Serious questions may be raised as to whether the entire "cost of acquisition" differential should be used to raise the earning rate on all equity, including stock which has already been issued. Much equity of the airlines was obtained at no financing cost, through retained earnings. Additional airline equity was obtained through convertible securities, which have a substantially lower financing cost. Is it necessary, in order to compensate for the fifteen per cent cost of acquisition which may be incurred in raising twenty-five per cent more equity, that the earning rate for the equity capital already acquired be also increased by this same amount? And how much, if any, "cost of acquisition" allowance is necessary when no new equity financing is contemplated? Notwithstanding these considerations, the Bureau counsel's witness concluded that a fifteen per cent increase of the earnings/market price ratios was equitable as a long-term industry allowance for "costs of raising equity capital."

c. Conclusions on cost of equity capital. Using these premises, the supply price of equity for the "Big Four" airlines would be computed as follows:

I. Earnings/market price ratio II. $0 \%$

2. Cost of equity acquisition allowance

3. Supply price of equity capital (II.0\%/.85 $=12.9 \%$ ) $I 5.0 \%$ $\mathrm{I} 2.9 \%$

Accordingly, Bureau counsel argued that 12.9 per cent was an objective measure of the cost of equity capital for the "Big Four" airlines and would enable them to attract equity capital on advantageous terms. ${ }^{57}$ Similarly, it was found that the supply price of equity capital for the smaller trunklines was I4.I per cent. ${ }^{58}$ These, of course, are not mathematically precise determinations, but merely indicate the midpoint of a zone or range of attractiveness.

\section{Determination of appropriate airline capital structure for rate-making purposes}

A major problem in using the "supply price" of capital in determining a fair and reasonable rate of return is the fact that various types of securities have different supply prices. In fact, giving effect to federal income tax rates of fifty-two per cent, it is found that airline equity capital is six to eight times more expensive than debt. Different capital structure proportions will, therefore, result in different over-all costs. What, then, is a reasonable or appropriate combination of the various types of securities under economic and efficient fiscal management? Basically, the appropriate structure is a compromise of the following factors:

I. the relative cheapness of debt securities; and

2. the need for an adequate margin of safety to maintain financial integrity.

${ }^{67}$ See Howell ExhIBIT $\$ 4$; BuRenU BrIEF I74-85.

sa Ibid. 
In the rate-of-return proceeding, the carriers urged a low debt ratio ranging from twenty-five to thirty per cent. The actual and prospective debt ratio, however, should be accorded careful consideration. The public should not have to pay the costs of a conservative debt structure and then not get what it pays for. Where the regulating authorities do not have control over financing, as they do not for airlines, they need not be bound by the actual structure. ${ }^{.0}$

For group rate-making, the capital structure must necessarily be a workable compromise. Such a compromise need not be stigmatized as "hypothetical" or "theoretical," and can be "fair and equitable." Debt ratios vary greatly among carriers and over time. Airline debt has ranged from over roo per cent for Capital to zero for Braniff. The regulatory authority must necessarily take a long-run, forward-looking, cross-sectional approach. At the hearings, the near-term capital structure for the "Big Four." was projected as approaching fifty per cent, and the remaining eight carriers projected a debt ratio of over fifty per cent. ${ }^{80}$

According to a fundamental canon of finance, the capital structure must be so set up that fixed charges can be covered at all times with a margin of safety. Coverage of senior charges is usually measured (a) in terms of "earnings available for fixed charges," or (b) on a "cash flow basis." In the case of the airlines, this "cash flow basis." is extremely significant because of the heavy depreciation write-offs. ${ }^{11}$ Margins by which charges should be covered are subject to differences of opinion and can be reviewed in textbooks on security analysis and bond investment. ${ }^{62}$

Among factors which indicate a strong future for air-transport business, and consequently an ability of the carriers to support substantial debt, are these:

I. speedy air transport is an essential for modern business and social life, as well as for national defense;

2. airline revenues have demonstrated great potential;

3. the Federal Aviation Act is promotional in objective and character; and 4. administratively, the air transport industry will not be permitted to "go to pot."

59 See Bureau BrIEF 196-200 for citation of authorities. For a "hands off" position on administrative control of airline finance, see Murray, Regulation of Airline Securities, Harv. Bus. Rev., May 1950, p. 7x. See also, testimony Hearings, infra note 64 passim.

${ }^{\circ 0}$ Extensive carrier projections are summarized in Howel Exhrbit $\$ 5$. See also Burenu Brier I 86-96.

${ }^{91}$ E.g., Eastern Air Lines has long followed a policy of writing off flight equipment in four years and at the same time accumulating a heavy overhaul reserve. When the equipment is sold, frequently at a price substantially higher than depreciated book value, the overhaul reserve is credited directly to surplus and thus becomes a hidden profit not reflected in the income statement. American Airlines is currently depreciating its piston equipment with the objective of complete replacement by $196 \mathrm{x}$. It has been held that the $\mathrm{CAB}$ is not empowered by statute to promulgate rules governing depreciation rates and policics.

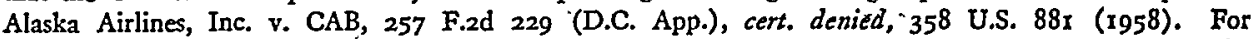
the BAO's argument for a seven-year 'depreciation period for piston equipment, see Burenu Briep I39-6r.

${ }^{62}$ See, e.g., Benjamin Graham \& David L. Dodd, Security Analysis (3d ed. I951); Ralph E. Badotir \& Harry G. Gutmanan, Investment Principles and Practices (4th ed. 1951). 
Experienced and informed finance officers charged with the fiduciary responsibility of safely handling other people's money have seen fit to make large and longterm loans to the airlines. It must be their considered judgment that these carriers are sound. ${ }^{63}$ Responsible airline managements, despite arguments of counsel and witnesses, have endorsed substantial debt ratios by (a) actual overt borrowings which, if excessive, would endanger the financial integrity of the carrier; and (b) by public statements on a number of occasions.

Officials have testified as to the appropriateness of substantial debt ratios for the industry. President W. A. Patterson of United Air Lines stated: ${ }^{64}$

. . 40\% debt ratio is not an unreasonable ratio. . . Debt capital has a definite and logical place in airline finance. Airline management should make use of debt, preferred stock and common equity capital in such proportions as to obtain the lowest cost for its total new capital requirements consistent with good conservative financial practice.

He emphasized the heavy depreciation cash throw-off, the higher cost of equity capital, the need to prevent dilution of earnings, and the essential nature of the industry.

Delta Financial Vice President T. G. Cole testified: ${ }^{65}$

It is our objective in looking at the years immediately ahead of us, the years that will see the acquisition and introduction of jet aircraft, to develop a capital structure of roughly $5^{\circ}$ per cent equity and $5^{\circ}$ per cent debt.

The Bureau's independent financial consultant testified that a forty per cent debt ratio was, when viewed from long-term considerations, financially sound and a fair balance of the interest of investors and consumers. Taking a forty per cent debt ratio with a four per cent debt cost, a I2.90 per cent equity cost, and a fifty-two per cent federal income tax, the fixed charges are covered more than eleven times. Coverage, after income taxes, would be six times. ${ }^{66}$

Bureau counsel, however, on the ground that prospective debt ratios would exceed forty per cent, urged the CAB to employ a forty-five per cent debt ratio for the "Big Four" trunk carriers. Also, on the basis of prospective debt ratios, Bureau counsel urged adoption of the less conservative debt ratio of fifty per cent for the smaller and weaker trunk carriers. ${ }^{67}$

${ }^{63}$ Most airline debt has been negotiated privately with insurance companies and commercial bankers, who should be skilled negotiators. Similarly, the investment bankers who underwrote debt issues offered to the public should be keenly interested in the ability of the airlines to service their obligations.

os Testimony of William A. Patterson, President, United Airlines, in Hearings Before the Senate Committee on Interstate and Foreign Commerce on S. 2647 , Revision of Civil Aeronatitics Act, $83 \mathrm{~d}$ Cong., $2 \mathrm{~d}$ Sess. 933-34 (1954); see also testimony of C. E. Woolman, President, Delta Airlines, echoing similar views. Id. at 935 .

os Testimony of Todd G. Cole, Financial Vice President, Delta Airlines, Suspended Passenger Fare Increase, No. 86r3, CAB, April 5, 1957, pp. 205-06. Also, R. G. Ferguson, Treasurer, Pan American World Airways, testified: "I believe that Pan American should not be forced to rely on debt for more than $45 \%$ of its total capitalization, that even this should continue only for short periods immediately following equipment delivered and that the goal should be to have in debt not over $40 \%$, and perhaps even less." Capital Gains Proceeding, No. 7902, PAA Exhibit, CAB, Oct. I956, p. I4.

${ }^{\circ 0}$ See Howelt. Exhibir $\$ 5$ and table V-2. 


\section{Over-all capital-attracting rate of return}

Combining the debt and equity components on a forty-sixty basis, an over-all supply price of capital of 9.34 per cent for the "Big Four" carriers results, as is shown in table one. Based on these calculations, a zone of reasonable rate of return might

TABLE I

Computation of Cost of Capital for Big Four

\begin{tabular}{|c|c|c|c|}
\hline $\begin{array}{l}\text { Type of } \\
\text { Security }\end{array}$ & $\begin{array}{c}\text { Capital } \\
\text { Structure }\end{array}$ & $\begin{array}{c}\text { Security } \\
\text { Cost }\end{array}$ & $\begin{array}{c}\text { Weighted } \\
\text { Cost }\end{array}$ \\
\hline Debt & $40.0 \%$ & $4.00 \%$ & $1.60 \%$ \\
\hline Equity & 60.0 & $12.90^{\circ}$ & 7.74 \\
\hline
\end{tabular}

range from 9.0 per cent to 9.7 per cent. These carriers account for about three-fourths of domestic trunkline revenue-passenger-miles. Similarly computed, the fair and reasonable rate of return for the smaller eight trunkline carriers was found to be ro.38 per cent, or about one per cent higher than that of the "Big Four."

Bureau counsel argued for a somewhat lower rate by using the actual debt ratios forecast by the carriers. A projected debt ratio of forty-five per cent gave an over-all return of 8.90 per cent for the "Big Four"; and a ratio of fifty per cent for the eight smaller (and weaker) trunk carriers resulted in a capital-attracting rate of return of 9.45 per cent. ${ }^{69}$ Most of the carriers contended for a rate of return in the neighborhood of twelve per cent.

\section{V}

\section{Other Aspects of Fixing Airline Rates}

In authorizing the 1956 General Passenger Fare Investigation, the Board stated that it should be confined to a consideration of the general level of rates. ${ }^{70}$ Questions of the competitive relationship of carriers, the structure of individual tariffs, discrimination, and so forth, were to be left to subsequent proceedings. But what started out to be a rate-of-return study has blossomed out to include many other

${ }^{68}$ Howell Exhibit $\$ 6$.

'Buread BrIEF 186-200. In setting mail subsidy rates for Mohawk Airlines, a local-service carricr, the Board, following the recommendations of the BAO, used $9.50 \%$ as the cost of capital. This figure was derived from a debt cost of $5.73 \%$, an equity cost of $14.47 \%$, and a capital structure consisting of $55 \%$ debt. See Mohawk Airlines, No. 7277, Opinion and Order No. E-12917, CAB, Aug. 28, 1958, and id. Order No. E-I3202, Nov. 26, x958. The present writer, as a financial analyst, takes strong issuc to the CAB's use of a heavier debt ratio for a weak subsidized local service than for the trunk line. In the Mohawk case, $\mathrm{CAB}$ member Minetti dissented, urging continued use of the old administrative $8 \%$ return until a decision is reached, after a careful study of the merits, in Rate of Return of Local Service Carriers, No. 8404 , Order No. E-10843, CAB, Dec. 10, 1956, a proceeding initiated over three years ago and still awaiting an examiner's initial decision. In the reopened Delta-C\&S Mail Rate Case-Initial Decision, No. $2564, \mathrm{CAB}$, June 20 , 1957, p. 2, Examiner Stodola found the cost of attracting capital to be 9.66\%. For administrative determinations, he used a $10 \%$ return on investment.

${ }^{70}$ General Passenger Fare Investigation, No. 8008, Order No. E-I0488, CAB, July 27, 1956, p. 2. 
things necessary to a sound determination of the character and quality of earnings. available. Among these are:

I. the adoption of a uniform fare level for all carriers;

2. the strong and weak carrier problem;

3. efficiency of operations and appropriate load factors;

4. stability and growth of earnings and elasticity of demand;

5. expense allowances and depreciation of piston equipment;

6. rate base, depreciation residual, construction deposits, and working capital allowances;

7. treatment of capital gains on sale of piston equipment; and

8. usefulness of piston data for jet operation projections.

A discussion of some of these is beyond the scope of this paper.

\section{A. Inadequacy of the Operating-Ratio Approach}

Half the carriers urged that the Board, in fixing rates, should place major, if not. complete, reliance upon the operating ratio as a means of fixing just and reasonable rates. Little was said about "just and reasonable rate of return."

The Board, by statute, is charged with the duty of "promoting" the industryFor carriers, the end objective is rates which will enable them to attract the necessary capital for buying modern jet equipment. To do this, uncommitted investors must consider the earnings sufficient to provide a fair return on their capital investment.

Operating ratio provides no guide to the supply price of capital-bonds or stock -and so it falls short of the market. Many investors have no idea what the operating ratio is. It varies a great deal from industry to industry, and also as to what items are included in its computation. ${ }^{72}$ Investors are interested in the return on their invested capital; there is no way of getting around that, and especially for an expanding utility. This earnings determination has to be made, and use of the operating ratio does not eliminate it. Every operating ratio ends up with some sort of return on capital. Indeed, questions of capital turnover are merely subordinate to the major end-the return on investment.

If the operating ratio provides a return below that which attracts capital, great agitation will soon arise to change it to provide a rate attractive to investors. If the operating ratio, as set, provides more than a capital-attracting rate of return, it ther becomes merely a device to obscure or camouflage an unconscionably high return on investment.

${ }^{71}$ See exhibits, related testimony, and briefs of Braniff, Capital, Western, Continental, Delta, and Eastern.

${ }^{73}$ See Moody's Manual of Investment, Public Utrumies ix (1957). With such diverse depreciation practices as those utilized by Eastern, United, and American, a single operating ratio would be meaningless. See note 6r supra. Also, the treatment for tax purposes of "accelerated depreciation" pursuant to INT. REv. CODE of I954, $\$ 167$ varies considerably. In this connection; see the discussion and statement of policy about accelerated depreciation in Treatment of Accelerated Amortization and Liberalized Depreciation Under Sections $I 67$ and I68 of the Internal Revenue Code for Rate of Return, No. I78I8, N.Y.P.S.C., March 30, 1959. See also Central Maine Power Co. v. Pub. Serv. Comm'n of Me., I53 Me. 228, 21 P.U.R.3d 321 (1957). 
To get a proper operating ratio would require even more detailed and tedious computations than would a straightforward rate-of-return approach. There could be no short cut effected merely by borrowing an operating ratio from some other industry, as was suggested by some of the airline testimony. ${ }^{73}$ Administrative procedures would not be lessened. Just as many fare changes would have to be made with use of operating ratio as with a cost-of-capital approach. ${ }^{74}$ The operating ratio approach is essentially a "cost plus" concept. Such a concept has many infirmities, the chief of which is that there exists little incentive to efficient and economical operation. Such a procedure is hardly justifiable in peacetime.

The significant question is not what is an appropriate operating ratio, but instead, what should be the "end result"? The operating-ratio approach, so far as indicated by the carriers' statistical exhibits, is incomplete. No objective data are presented to show what the operating ratio for air carriers should be, and why it should be at this particular level. A high operating ratio or high capital turnover does not automatically mean higher risk. The operating-ratio approach gears profit to volume of business and not to efficiency, the amount of capital dedicated, or the supply price of that capital.

\section{B. Efficiency of Operations and the Load Factor}

The carriers are entitled to a reasonable return under "economical and efficient management." The difficulty, of course, is the old one of finding adequate standards to measure efficiency. In the case of airlines, with varying routes and traffic patterns, this is quite complicated.

In determining fare levels needed to produce a reasonable return on capital, one must consider the appropriate utilization of plant capacity. Utilization of an aircraft can be broken down into three parts: (a) the number of hours the aircraft is in use; (b) utilization of the interior-i.e., seating configuration or number of seats installed; and (c) utilization of installed seats, or load factor. Most attention has been fixed on utilization of installed seats.

At the outset, the question must be faced: Upon what load factor should fares be predicated in setting rates? A carrier with a high load factor can make a high rate of return even though fares are very low. In contrast, if utilization of seats is low, the company will lose, no matter how high its fares.

How heavily, managers must ask themselves, should the carrier saturate a given route with schedules in relationship to available traffic? Frequent schedules generate more business, but at diminishing returns. Likewise, if there are competitors on the route, how much equipment should be utilized to duplicate the other schedules in order to get traffic away from them. This could turn into cut-throat competition.

\footnotetext{
${ }^{73}$ See Rickenbacker, The Operating Ratio as a Yardstick for Measuring Airline Profits, 20 J. Ain L. s: Com. 253 (1953). For a critical comment, see Grossman, Reasonable Operating Ratio Vcrstis Fair Rate of Return, 2I J. Alr L. \& COM. I5 (1954): For a general discussion of the use of the operating ratio by the ICC in motor-carrier regulation, see Arrchison; op. cit. supra note 6.

74 For a thorough analysis of the shortcomings of the operating ratio approach, see Knappen, Transit Operating Ratio-Another View, 51 PuB. UTiL. Forr. 485 (1953).
} 
The Board has said, however, that the carriers will have competition, that they must learn to live with it, and that fares must be based on a reasonable load factor. ${ }^{75}$

If air transport is to be promoted, it needs to have many available seat miles; on the other hand, the seat miles can only be filled by keeping fares down. This situation, of course, brings up the question of elasticity of demand. A direct conflict arises between raising fares to cover costs, ${ }^{76}$ and the need for keeping fares low to fill the seats and thus spread overhead.

One way to improve the over-all load factor is to get rid of poorly utilized piston equipment as rapidly as possible. The $\mathrm{CAB}$ staff has contended that fares should be based on a load factor of about sixty-three per cent, the average for the five-year period, 1953-58. The industry has urged the adoption of no higher than sixty per cent. At any given time, the annual load factor will vary as much as ten percentage points among different trunkline carriers. If fare levels are set to make operations profitable to the majority of the business-three-fourths of which is done by the "Big Four"-it may make profits extremely skimpy for poorly situated carriers. This, again, is the strong-and-weak-carrier problem, with which the ICC has been wrestling for some forty years.

\section{The Treatment of Aircraft Construction Advances}

When a property-rate base is used instead of an invested-capital base, great care must be taken with respect to the items included. Otherwise, the application of a market earnings rate to a nonmarket base will not provide earnings attractive to invested capital. All too frequently, regulatory commissions have been skimpy in their allowances for capitalization of return on work-in-progress, or in allowances for working capital during a lengthy construction period. The orthodox treatment excludes property from the rate base until it is put "on stream" and is rendering service. Current costs of construction, it is considered, should be capitalized and charged against future users of the property. When a railroad buys a locomotive, that is all taken care of in the purchase price. When an electric company builds a large power plant for itself, a credit is given to "interest during construction."

The airlines, like the railroads, have the construction done for them, but with a major difference. The aircraft manufacturers are inadequately financed and require substantial deposits as the construction progresses; these deposits for jet financing are large relative to total airline capital. Consequently, allowances for "nonproductive" deposits is a most important matter. For example, as of the end of 1958 , "advances to suppliers for aircraft under construction" amounted to over $\$ 43,000,000$ for Eastern Air Lines, or twenty-three per cent of net property and equipment.

\footnotetext{
${ }^{70}$ Suspended Passenger Fare Increase, No. 8613, Order No. E-11812, CAB, Sept. 25, 1957, pp. 29-33.

${ }^{70} \mathrm{~A}$ good deal of confusion exists in discussion of costs. Is it the cost of a unit being purchasedi.e., a wage per hour or gallon of gasoline-or is it cost of unit being sold-i.e., available seat-mile or revenue seat-mile? In general, although the unit cost of items purchased has been going up, the increased productivity of larger and faster aircraft has kept the seat-mile costs fairly stable. For a presentation of the BAO position concerning "elasticity of demand" for air travel, see BuREAU BrIEF 293-317.
} 
Two important questions arise: Should the deposits and a reasonable amount of anticipatory financing (construction working capital) be included in the airline rate base? If not included in the rate base, what rate of return should be used to capitalize the construction investment? ${ }^{77}$

A regulatory commission's treatment of "interest during construction" is often inadequate. "Interest during construction" should not be limited to "interest rates" on borrowed funds, as is done by the Internal Revenue Service. The over-all capitalattracting rate of return should be used in capitalizing construction costs, regardless of whether there is heavy bank borrowing. If there were not substantial equity already in the business, bank borrowing would be impossible.

Furthermore, working capital allowances must be more substantial when heavy construction is going on. The cost of this money is a most legitimate expense of providing service to the public. If the Brandeis approach is used, these problems fade into the background. The total of the capital prudently invested is the true rate base and is the proper partner for a rate of return determined by the market supply price of free funds.

\section{VI}

\section{Promotional Rates and Jet Aircraft Financing}

The objective of the 1956 General Passenger Fare Investigation is to set fare levels which will encourage and promote expansion and utilization of service. In the present setting, this means fares which will enable the airline not only to attract capital to consummate their jet equipment program, but also to fill those jet airplanes with passengers.

Here the basic question is: Does the word "promote," as used in the Federal Aviation Act, apply to technology and service, or does it have some special application and meaning for finance? If rates and fares are sufficient to provide earnings which attract the necessary capital, is not the inquiry at an end? Does promotion with respect to finance mean something more? If rates are sufficient to attract capital, would not increased fares and earnings provide something more than is necessary? If adequate earnings are at hand, it has been demonstrated that airlines can attract capital on advantageous terms. The basic question has never been whether the carriers could finance on a twelve per cent but not on an eight per cent return. The carriers which have had difficulty are those which have not been able to earn a reasonable return measured by any standard. Carriers with poor earnings records, like Capital and Northeast, have not yet been able to order modern jet equipment, although each has been operating Viscounts for some time.

In setting rates, it is important to remember that consumers are passengers and are not a source of capital, which is to be furnished by investors. Consumers have an obligation to pay for the service or use of the capital; but they never get any

\footnotetext{
${ }^{72}$ See James C. Bongright, Principles Underlyinc the Capitalization of Interest Durino Con. STRUCTION (1953).
} 
dividends. Some utterances by industry spokesmen appear to confuse these distinct functions-one of furnishing the capital, and the other of paying for its hire.

\section{VII}

\section{The Hearing Examiner's Initial Decision}

On May 27, 1959, Hearing Examiner Ralph L. Wiser, releasing his long-awaited Initial Decision in the 1956 General Passenger Fare Investigation, declared that ro.6 per cent was a fair and reasonable return for trunkline air carriers. ${ }^{78}$ This was, indeed, a landmark decision, since this over-all rate is the highest ever to be granted since the beginning of effective regulation over fifty years ago. ${ }^{79}$ Along with a companion decision of FPC Hearing Examiner Zwerdling as to return allowances for natural gas producers, ${ }^{80}$ it constitutes required reading by serious students for contrasting approaches and "end results." In the space available, one can comment only on a few high points.

\section{A. Debt Cost}

Writing from the vantage point of twenty months after the preparation of exhibits, when interest rates were considerably lower, Wiser concluded 4.5 per cent and 5.5 per cent to be reasonable allowances for the cost of debt for the "Big Four" and the smaller eight carriers, respectively. The recent increase in the prime money rate and the New York Federal Reserve Bank rediscount rate, and the April r959 sale by American Airlines of $\$ 70,000,000$ of notes and subordinated convertible debentures at five per cent support this conclusion.

\section{B. Cost of Equity Capital}

Wiser concluded that the earnings/price ratio for the "Big Four" was thirteen per cent, to which he added two per cent for intangible factors. He similarly concluded that seventeen per cent was the cost of attracting equity for the smaller carriers. Wiser did not state what time period he was using, nor whether he included capital gains in the earnings figures. Neither did he indicate whether he would give more weight to recent market capitalization data than to the more distant high earnings/price ratios resulting from swollen temporary profits of the Korean traffic. Nor was his treatment of financing costs particularized.

Wiser then discussed the return on book equity of manufacturing corporations, without apparently realizing that this does not constitute a true market capitalattracting rate. This does not represent what investors will pay for a dollar of earnings. There are so many intangible factors involved, including wide variations

\footnotetext{
${ }^{78}$ General Passenger Fare Investigation, No. 8008, CAB, May 27, 1959 , consisting of 187 pages of text (mimeographed), and II4 pages of appendix [hereinafter cited as WISER Deciston].

7' Sec Arthur andersen \& Co., Return Allowed in Public Utility Rate Cases (i958).

${ }^{80}$ Matter of Phillips Petroleum Co., No. G-r 4 8, Initial Decision FPC, April 6, 1959, a proceeding under $\$ \$ 4(\mathrm{e})$ and $5(\mathrm{a})$ of the Natural Gas Act, 52 Stat. 822,823 , I5 U.S.C. $\$ \$ 717 \mathrm{c}, \mathrm{d}(\mathrm{a})$ (1952). See also Colorado Interstate Gas Co., 19 F.P.C. 1024 (1958).
} 
in accounting practices of industrial companies as compared with regulated companies, that comparisons of earnings on book value have little significance. $\mathrm{He}$ further concluded that "air carriers are relatively comparable in risk to . . . manufacturing companies...." \$I If this were so, it would have been far more appropriate to consider the earnings/market price ratios of such industrial companies rather than the return on loosely defined book value. The average earnings/market price ratios for manufacturing companies for the past five years ${ }^{82}$ has been about 7.3 per cent. ${ }^{83}$ For the period I95I-58, Moody's Manuals show it to be about 8.3 per cent. If Wiser had looked to immediately present and prospective future equity costs, as he did in the case of debt, he would find that his thirteen per cent earnings/price ratio allowance (ignoring his two per cent additional allowance for intangibles) was almost twice that of industrial concerns.

It is interesting to compare Wiser's results with that of other regulated enterprises. The degree of risk comparability must be left to the reader and to the market. FPC Hearing Examiner Zwerdling, in the celebrated Phillips case, found, following FPC staff testimony, that ten per cent was a reasonable cost of equity capital for gas producers. ${ }^{84}$ Drilling for gas and oil has historically been considered the classic case of risk-taking, or speculative, enterprise. To find that a semimonopolistic public utility business, in an essential industry backed up by government subsidies, is as risky as gas drilling strains traditional views. To say that the cost of raising airline equity is fifty per cent more than that of the natural gas drilling business does not seem to reflect the relative economic facts. In this connection, it might be well to re-read the Bluefield case, quoted by Wiser $:^{85}$

A public utility is entitled to such rates as will permit it to earn a return on the value of the property which it employs for the convenience of the public equal to that generally being made at the same time and in the same general part of the country on investments in other business undertakings which are attended by corresponding risks and uncertainties; but it has no constitutional right to profits such as are realized or anticipated in highly profitable enterprises [leading manufacturers] or speculative ventures [gas].

${ }^{81}$ Wiser Decision 45. A recent study, Sidney Cottre \& Tate Whitman, Corporate Earnino Power and Market Valuation, 1935-1955, at 35-37 (I959), indicates that there is also little or no relation between the level of price-earnings ratios and the rate of return on invested capital.

${ }^{82}$ Wiser frequently makes use of a five-year moving average.

${ }^{88}$ Moody's averages of 125 industrial companies shows the following earnings/price ratios:

$\begin{array}{lccc}1951 & 10.4 \% ; & 1955 & 8.0 \\ 1952 & 9.5 & 1956 & 6.9 \\ 1953 & 10.1 & 1957 & 7.1 \\ 1954 & 8.7 & 1958 & 5.6\end{array}$

Moody's Investor Service, Industrial Manual (1959).

${ }^{84}$ Matter of Phillips Petroleum Co., No. G I148, Initial Decision, FPC, April 6, 1959. Because of a small amount of debt at $3.5 \%$, the examiner concluded that an over-all rate of return of $9.25 \%$ was "fair and reasonable" for Phillips.

${ }^{85}$ Bluefield Water Works \& Improvement Co. v. Pub. Serv. Comm'n of West Virginia, 262 U.S. 689, 692 (1923). (Emphasis added.) 


\section{Capital Structure}

In determining the appropriate proportions of debt and equity to get an over-all return, Wiser used the "forward look"-the average forecast debt ratios, which were termed "the actual." These were forty-five per cent for the "Big-Four" and fifty per cent for the weaker carriers. Much is to be said in favor of the use of actual figures where it cannot be asserted there is an absence of economical and efficient management. Debt averages could be of the past, as in the case of equity ratios, or a mixture of past, present, and prospective. If weight were given to the recent past, the averages would be close to forty per cent. One must be careful to see that these prospective averages do not have the limitations of "spot" observations. It is, of course, financial topsy-turvy to use a heavier debt structure for weaker companies, and this could lead to the nonsensical result of a lower over-all rate of capital for poorer companies.

\section{Over-all Rate of Return}

On the basis of prospective capital structures, Examiner Wiser found an over-all cost of capital of r0.25 per cent for the "Big Four" and Ir.25 per cent for the remainder; weighting them, he got 10.6 per cent for the industry. It will, indeed, be interesting to compare how the $\mathrm{CAB}$ and the FPC deal with the recommendations of their respective examiners. If the Board accepts Wiser's over-all conclusion of Io.6 per cent as a reasonable weighted fair rate of return for an industry that is now the largest common carrier of passengers in the world, ${ }^{86}$ it will be the highest in history. ${ }^{87}$ This will be in the face of the fact that the carriers managed to grow from weak operating and financial infancy to become a burgeoning giant, whose securities are actively recommended by leading investment bankers, ${ }^{88}$ at a rate of return substantially less than Io.6 per cent. To say that the carriers now require ro.6 per cent to "carry on" just does not seem to reflect the economic facts.

\section{E. The Operating Ratio}

The operating-ratio approach was dismissed as containing many "subtle fallacies," 80 for "the most significant test of a reasonable operating ratio shown in the record is whether it brings a fair return on investment thus making it impossible to avoid the necessity of reaching a finding on the latter whenever the conditions as to capital charges change." The more complex the proceeding, the more efficient and equitable it is to reach this result directly, rather than to attempt it indirectly through an operating ratio approach, over which there is a great diversity of opinion and treatment.

${ }^{80}$ The 12 United States domestic trunk lines now carry more passenger miles (excepting commuters) than all United States railroads combined. This transportation amounts to nearly $30,000,000,000$ passengermiles per year and has gross revenues exceeding $\$ \mathrm{r}, 500,000,000$.

${ }^{87}$ It may be interesting to note, in passing, that since the beginning of regulation in the United States, no major rate-of-return allowance has exceeded $8 \%$. During the past 25 years, none has exeeded $7 \%$. Sce Arthur Andersen \& Co., op. cit. supra note 79.

${ }^{88}$ See special airline investment studies of Shields \& Co., May 1959; Brown Brothers Harriman \& Co., March I 8 and 25, 1959; and Carl M. Loeb, Rhodes \& Co., May 1959.

${ }^{80}$ Wiser Decision 74. Cf. Local Service Carriers, No. 8404, Initial Decision, CAB, July I3, I959.

${ }^{\circ}$ Id. at 83 . 


\section{F. The Load Factor}

Wiser declined, as inconsistent with statutory mandate and Board policy, to fix standards of service such as a specific load factor of sixty-three per cent as requested by Bureau Counsel. Reliance should be placed "primarily upon competition rather than rigid Government imposed standards to develop advantageous quality and cost levels (which) will encourage development of productivity to the utmost."101

\section{G. Rate Base-Construction Advances}

As urged in the early part of this paper, Wiser follows the logic of the Brandeis approach that the rate base depends on capital which is committed to utility service. $\mathrm{He}$, therefore, includes aircraft equipment construction advances.

\section{EpILogue}

The handing down of the examiner's opinion, over one-half a year after the filing of briefs, marked merely another step in a protracted proceeding. Thereafter, briefs were, again, filed, and oral argument was held before the Board on July 28-29, I959. Since then, two of the five commissioners have resigned, and the resignation of another is expected momentarily. This may necessitate a re-argument and a decision by a new and inexperienced Board on one of the most important cases ever brought before it. Following a delayed Board opinion, the matter may then possibly be judicially reviewed. By this time, however, the industry will have been well launched into jet air operations, and both the economic and the operating data will be obsolete. Jet costs have already been demonstrated to be less than those of the latest piston-operated aircraft, ${ }^{22}$ and there are strong indications that "available seat-miles" will be.coming out of the carriers' ears unless new markets are tapped.

Rate of return, like other regulatory matters, to be effective, should be a continuing and up-to-date matter. It should be carefully reviewed every three to five years. But if a rate proceeding takes several years, there is a breakdown. There should, at least, be a breathing spell between rate cases. The 1956 General Passenger Fare Investigation has been essentialy a "trial by combat," with everyone insisting on his legal rights, little cooperation, the assumption of exaggerated positions to bargain for something less, delaying tactics, extremely diverse positions of the carriers, and so on. Issues were tried in the press, became embroiled in general politics and congressional investigations, and there were even overtones from the White House. ${ }^{93}$

The proceeding lacked focus. It was months after the initiating order was drawn before the issues to be investigated were decided upon, and only after much wrangling discussion. Much of the lack of direction resulted from the lack of unity within the

${ }^{91} I d$. at $12 \mathrm{x}$.

${ }^{02}$ In a formal address before the Ncw York Society of Security Analysts, Oct. 23, 1959, Mr. C. R. Smith, President, American Airlines, stated: "We have proved to our satisfaction that the jet airplane can produce air transportation on a more economical basis than the historical costs for the DC-7." (Emphasis added.)

${ }^{03}$ Hearings Before a Special Subcommittee of the House Committee on Interstate and Foreign Commerce on Legislative Oversight, 85 th Cong., Ist Sess. passim (1958). 
Board itself as to what, if anything, should be done. Even intervening governmental agencies, like the Department of Defense and the General Services Administration, had no firm or cohesive policy in their participation. Budget appropriations for an adequate staff were lacking.

The 1956 General Passenger Fare Investigation has been too much of an omnibus case. Many matters should have been disposed of years before and a firm policy formed. Such a policy determination would have eliminated long ago issues like the rate base, allowable expenses, construction deposits, working capital allowances, depreciation periods, control over carrier accounts, and the treatment of weak carriers. This, in turn, would have simplified and expedited the determination of what return is necessary to attract capital. The present troubles are part of the growing pains of a new industry which is now "going into orbit." 